\title{
Workplace Mobbing and Effects on Workers' Health
}

\author{
Mariano Meseguer de Pedro, María Isabel Soler Sánchez, \\ María Concepción Sáez Navarro, and Mariano García Izquierdo \\ Universidad de Murcia
}

\begin{abstract}
In this work, we analyze various consequences of the phenomenon of mobbing on the health of a work sector with special characteristics: the agro fruit sector. For this purpose, we collected data from a sample of 396 workers ( 61 men and 331 women) belonging to this sector in the Region of Murcia (Spain). A questionnaire with the following measurement instruments was administered: a Spanish adaptation of the revised Negative Acts Questionnaire (Sáez, García, \& Llor, 2003), the Psychosomatic Problems Questionnaire (Hock, 1988), and a measure of absenteeism. The results revealed a significant and positive relation between workplace mobbing and psychosomatic symptoms, but not with absenteeism. The implications of the results for future research are discussed.

Keywords: mobbing, psychosomatic symptoms, absenteeism
\end{abstract}

En el presente trabajo analizamos distintas consecuencias del fenómeno del mobbing en el trabajo en un sector con características especiales como es el hortofrutícola. Para ello recogemos los datos de una muestra de 396 trabajadores (61 hombres y 331 mujeres) pertenecientes a este sector en la Región de Murcia. Se administró un cuestionario con los siguientes instrumentos de medida: NAQ-RE (Sáez, García y Llor, 2003), CPP (Hock, 1988) y una medida de absentismo. Los resultados indican la existencia de una relación significativa y positiva entre mobbing en el trabajo y síntomas psicosomáticos, pero no con el absentismo. Se discuten las implicaciones que para la investigación futura tienen los resultados obtenidos.

Palabras clave: mobbing, problemas psicosomáticos, absentismo

Correspondence concerning this article should be addressed to Mariano Meseguer de Pedro, Universidad de Murcia, Facultad de Psicología, Campus Universitario de Espinardo. Edificio Luis Vives, 30100 Espinardo, Murcia (Spain). Phone: 968.36.76.97. Fax: 968.36.41.15. E-mail: marianom@um.es

Translation: Virginia Navascués Howard 
Mobbing is a complex phenomenon that is often expressed as hostile, repeated, undesired, and unreciprocated behaviors that can have a devastating effect on the victim (Di Martino, Hoel, \& Cooper, 2003). Workers who are the target of mobbing are exposed to a broad variety of hostile behaviors that range from permanent criticism of their work, detrimental comments, malicious gossip, attacks on their religious or political attitudes, or even threats and acts of physical violence (Einarsen, 2000).

Mobbing has been considered a severe social stressor (Zapf, 1999), a traumatic vital event (Wilson, 1991), a silent epidemic that causes job dissatisfaction, psychological distress, and psychosomatic and physical problems. In 1976, Brodsky predicted that the consequences for workers, organizations, and society would be devastating.

Leymann $(1990,1996)$ classified harassing behaviors in five categories: (a) targeting self-esteem and the means of communication (restricting possibilities of communication, preventing contact with others, etc.); (b) attacks on personal social relations (limiting the possibilities of maintaining contact with others, isolating the person from the others, etc.); (c) attacks on the person's reputation (spreading rumors, making fun of the person or of a discapacity, etc.); (d) attacks on the person's professional quality and the life situation (not assigning meaningful tasks, assigning tasks that are below the person's personal qualification, etc.); and (e) attacks on the person's health (assigning dangerous tasks, physical threats, sexual harassment, etc.). Likewise, other authors, using the Leymann Inventory of Psychological Terror (LIPT; Leymann, 1990) ) or the Negative Acts Questionnaires (NAQ; Einarsen \& Raknes, 1997) and various factor analyses, have proposed other taxonomies of mobbing behaviors (Hoel \& Cooper, 2000; Einarsen \& Raknes, 1997; Vartia, 2001; Zapf, Knorz, \& Kulla, 1996).

Regarding the consequences for the harassed victims, it should be noted that most of the works that relate health to mobbing were carried out with victims who had generally suffered a long process of harassment (Brodsky, 1976; Einarsen, Matthiesen, \& Skogstad, 1998; Gandolfo, 1995; Keashly \& Harvey, 2006; Leymann \& Gustafsson, 1996; Llor, García-Izquierdo, Campillo, Ruiz, \& Luna, 2004; Mattiesen \& Einarsen, 2001; Mikkelsen \& Einarsen, 2002; Vartia, 2003). Therefore, in studies with samples of workers in general, in which victimization processes may not be so severe, it is unclear whether there are also significant associations with health and well-being.

Thus, Einarsen and Raknes (1997), with a sample of employees from Norwegian dockyards, found that exposure to mobbing explained $23 \%$ of the variance of psychological health and well-being. Previously, Einarsen, Raknes, Matthiesen, and Hellesoy (1996) associated the experience of mobbing with psychological, psychosomatic, and muscular-skeletal problems. Kaukiainen et al. (2001) concluded that there were significant differences in physical symptoms, affective and cognitive problems, and social problems between the people classified as "victims" from an operative viewpoint and those who were not victims.

Doubtless, investigations in global samples, not exclusively in victims, will contribute to a better understanding of the phenomenon and its escalation and, from the viewpoint of work risk prevention, to finding indicators that will allow us to act before the problem reaches advances phases of the victimization process. Taking the above into account, the main goals of this work are: (a) to analyze the relations of mobbing with stress-related psychosomatic symptomatology and work absenteeism in a global sample of workers from a specific sector-agro fruit workers-; and (b) to identify the mobbing factors that predict stress-related psychosomatic symptoms.

\section{Method}

\section{Participants}

The subjects of our study belonged to various companies of the sector of Producers of Fruit and Vegetables located in the Region of Murcia (south-eastern Spain). As typical of this kind of industry, it integrates the production area (fieldwork) with that of product manipulation and commercialization (warehouse). The number of people who participated was 406. Eight questionnaires were eliminated because they were incomplete or had errors.

Regarding gender, 61 participants were men (15.4\%) and 331 women $(83.6 \%)$, and $4(1 \%)$ did not include this datum. With regard to civil status, 213 people $(53.8 \%)$ were single, $147(37.1 \%)$ were married, $25(6.1 \%)$ were separated or widowed, and $11(2.8 \%)$ did not respond to this item. Mean age of the sample was 28.68 years $(S D .=6.35$, ranging from 18 to 58 years) and the mean length of employment with the company was 27.14 months $(S D=$ 29.06 , range 1 to 236 months).

According to their educational level, 156 people (39.4\%) had primary studies, $112(28.3 \%)$ had achieved the title of "School Graduate," 84 (21.2\%) had first or second level of Professional Training or High school, 31 (7.8\%) had higher studies, either a diploma or a licentiate degree, and $13(3.3 \%)$ did not include this datum.

Regarding the kind of contract, we obtained a typical representation of this sector: 181 workers $(45.7 \%)$ had a time-limited contract, $168(42.4 \%)$ had a discontinued fixed contract, and only $23(5.8 \%)$ had an unlimited contract. Twenty-four people $(6.1 \%)$ did not include this item.

Taking the workers' origin into account, the majority are Spaniards, 302 people (76.3\%), followed by $45(11.4 \%)$ South Americans, 26 (6.6\%) Moroccans, and 11 (2.8\%) from Eastern countries, Sub-Saharan, or from Central Europe. Twelve people (3\%) did not include this item.

Regarding the position, 342 people (86.36\%) carried out basic tasks (packers, unskilled laborers, canners, cleaners, 
drivers, etc.), 31 people (7.82\%) held posts as supervisors, technicians, or administrative personnel. Twenty-three people $(5.8 \%)$ did not answer this item.

Summing up, the sample can be described as mostly female, single, with a low educational level. The majority of the workers were Spanish, with a time-limited or discontinuous fixed contract and with assistantial coverage in the "Régimen Especial Agrario" (in English, the Special Agrarian Regime). This is a fairly good description of the population working in warehouse-related tasks of the agriculture sector (Consejo Económico y Social de la Región de Murcia, hereafter, CES, 2003-in English, the Economic and Social Council of the Region of Murcia).

\section{Instruments}

To assess workplace mobbing, we used the Negative Acts Questionnaire (NAQ-RE), a revision of the Spanish adaptation of the NAQ-R (Einarsen \& Hoel, 2001), carried out by Sáez, García-Izquierdo, and Llor (2003). This scale requests respondents to indicate the frequency with which one of the 24 negative acts has occurred at work in the last 6 months, on a 5-point Likert type rating scale, ranging from 1 (never) to 5 (daily). As item examples: "you are insulted verbally," "your points of view and opinions are not taken into account," "you are deprived of responsibility in work tasks." None the terms of the NAQ-RE refer to the word mobbing. By means of factor analysis of the NAQ-RE carried out in previous investigations (Meseguer, 2005), using a measure of optimum sample adequacy $(\mathrm{KMO}=.89)$, the following components were extracted:

Personal Bullying (NAQ1), comprising 8 of the 24 scale items (for example, "people make comments to you that you consider ridiculous or insulting," "you are insulted verbally," or "you feel you are the target of practical jokes."), This component had an internal consistency of .85 (Cronbach's alpha) and it accounted for $30.98 \%$ of the variance.

1. Work-Related Bullying (NAQ2) includes 5 items from the scale. Items such as "your questions or attempts to participate in conversations are met with silence" or "the result of your work is undervalued" load on this component (Cronbach's $\alpha=.81$ ). It explains $7.19 \%$ of the variance.

2. Age- or Gender-Related Bullying (NAQ3) is made up of 5 items that refer to aspects such as: "your rights and opinions are undervalued depending on whether you are a man or a woman" or "your rights and opinions are undervalued because of your age" (Cronbach's $\alpha=.67$ ). It explains $6.48 \%$ of the variance.

3. Organizational bullying (NAQ4), made up of 3 items, refers to aspects like "you are ordered to perform work that is beneath your level of competence or preparation" or "you are deprived of responsibility in work tasks" (Cronbach's $\alpha=.65$ ). It explains $5.11 \%$ of the variance.

4. Other Forms of Bullying (NAQ5), which groups 3 items such as "you receive unwanted attention because of your sex" and "you feel exploited at work" (Cronbach's $\alpha=.60$ ). It accounts for $5.05 \%$ of the variance.

Stress-related psychosomatic problems were measured by means of the Psychosomatic Complaints Questionnaire (PCQ), adapted in Spain by García-Izquierdo, Castellón, Albadalejo, and García-Izquierdo (1993), which was in turn based on the Teacher Burnout Questionnaire (Hock, 1988). In this questionnaire, participants are requested to indicate on a 6-point Likert-type scale ranging from 1 (never) to 6 (quite frequently) whether they have suffered in the past 3 months from any of the 12 symptoms described. Item examples include: "migraines and headaches," "indigestion or upset stomach," or "loss of appetite." Its internal consistency was .89 (Cronbach's $\alpha$ ).

Two items were included to measure work absenteeism: a closed question (yes / no), asking "were you on leave in the last 6 months?" and an open question about the motive of the leave of absence. For the first item, participants were also requested to indicate how often they were on leave during that interval.

\section{Procedure}

This investigation falls within the framework of the assessment of workplace risks of a psychosocial nature. The design of this study was proposed in some initial meetings with the company managers and the people responsible for work health. A questionnaire designed for this purpose, including data about sociodemographic and work variables, mobbing, and stress-related psychosomatic problems, was administered individually during working hours, in the company buildings, to all personnel who were present on the days the assessment took place. Work risk prevention technicians, who were not part of the company staff, were in charge of giving the appropriate instructions to complete the questionnaires, ensuring the workers of their anonymity, and clarifying any doubts that arose when responding. Mean session duration was 60 minutes.

\section{Results}

To assess the incidence of mobbing, we used the NAQRE results according to the suggestions of Mikkelsen and Einarsen (2001), who, from an operative viewpoint, proposed a criterion of two or more behaviors at least "once a week" in the past 6 months. With this criterion, 111 workers could be considered to be suffering from mobbing; this represents $28 \%$ of the sample. 
Regarding the following frequency percentages of the bullying behaviors described in the questionnaire are noteworthy: "the effort you make in your work is undervalued" (47.7\%), "you feel exploited at work" (44.1\%), "the result of your work is undervalued" (45\%), "your points of view and opinions are not taken into account" (40.5\%), "you hear gossip or rumors" (27.9\%), "you are persistently reminded of your errors" (24.3\%), and "necessary information is withheld, making your work is more difficult" (24.3\%). In general, the most frequent hostile behaviors were related to work performance and its results.

When determining the percentage of stress-related psychosomatic symptomatology, we selected the "relatively frequently" and "quite frequently" response categories. The following items and percentages were notable: "a sharp pain or painful sensations in various parts of my body" (PS10, $30 \%$ of the sample); "a strong temptation to stay in bed in the morning" (PS11, 27.5\%); "a feeling of extreme fatigue or exhaustion" (PS4, 25.5\%); and "migraine or headaches" (PS2, 23.8\%). The percentages can be seen in more detail in Table 1.

Regarding the relation of psychosomatic symptoms with mobbing, the results showed a positive and statistically significant association, $r=.512, p=.000$. Specifically, we analyzed the 12 items of the scale of psychosomatic complaints and compared the groups of "nonvictims" and "victims." For this purpose, we applied Student's $t$ test, and we estimated effect size with Cohen's $d$ index (see Table 2), finding that, in 7 out of the 12 symptoms that make up the PCQ, there was a medium or high statistically significant difference between the two groups. And 5 of them had of a magnitude $(d>.20)$ that indicates practical or social significance (Cohen, 1988) although the relation was low.
In addition, to verify the effects of mobbing in psychosomatic symptomatology, we categorized the sample into "cases of stress" and "no stress," according to the criterion established in the surveys about work conditions carried out by the Instituto Nacional de la Seguridad e Higiene en el Trabajo (National Institute of Workplace Safety and Hygiene; see Ministerio de Trabajo y Asuntos Sociales [Ministry of Work and Social Affairs], 2004), by which any worker who presents a combination of three or more psychosomatic symptoms is considered a possible case of stress. A contingency table (see Table 3 ) with these categories and the groups of victims / nonvictims of mobbing was constructed, and we applied the chi square test, finding statistically significant differences between the groups, $\chi^{2}(1, N=2)=45.25, p=.000$, Cramer's $V=$ .34. Upon examination of the standardized residuals of the contingency table, it was observed that only $22.5 \%$ of the nonvictim participants could be categorized as cases of stress, whereas this percentage is twice as high $(47.7 \%)$ for the group of victims. The broadest standardized residuals are present in this group (-3.2 and 4.7, respectively)

Concerning the association of mobbing with work absenteeism, 102 employees stated they had taken leave (26.3\% of the sample). Out of this total, $32 \%$ were classified as victims, compared to $24 \%$ who were nonvictims. To verify this effect statistically, we used Student's $t$ test for independent samples and the estimation of effect size, using the total NAQ-RE score and the response categories of absenteeism (yes or no). The mean for the group that had been on leave during the past year was 37.99 , whereas for the group that had not been on leave, it was 34.05. This difference was statistically significant $(p<.05)$, as shown in Table 4, although the estimation of the effect size yields

Table 1

Percentage of Participants who suffered from Psychosomatic Symptoms

Psychosomatic Complaints Questionnaire PCQ

(Response categories: relatively frequently and quite frequently)

\begin{tabular}{llr}
\hline Item $n^{\text {o }}$ & Item content & $\%$ \\
\hline PS1 & Impossible to get to sleep & 14.7 \\
PS2 & Migraines and headaches & 23.8 \\
PS3 & Indigestion or gastrointestinal complaints & 10.9 \\
PS4. & Feeling of extreme fatigue or exhaustion & 25.5 \\
PS5 & Tendency to eat, drink, or smoke more than usual \\
PS6 & Reduced sexual interest & 19.7 \\
PS7 & Troubled breathing or feeling of suffocation \\
PS8 & Loss of appetite & 8.8 \\
PS9 & Muscular trembling (i.e., nervous tics, twitching eyelid, etc.) \\
PS10 & Sharp pains or painful sensations in various parts of the body \\
PS11 & Strong temptation to stay in bed in the morning \\
PS12 & Tendency to sweat or palpitations \\
\hline
\end{tabular}


Table 2

Student's t Test for Independent Samples. Comparison of Psychosomatic Symptoms in Victims and Nonvictims

\begin{tabular}{|c|c|c|c|c|c|c|c|c|c|}
\hline \multirow{2}{*}{ Item } & \multicolumn{2}{|c|}{ Nonvictims $(n=285)$} & \multicolumn{2}{|c|}{ Victims $(n=111)$} & \multirow[b]{2}{*}{$T$} & \multirow[b]{2}{*}{$d f^{*}$} & \multirow[b]{2}{*}{$p$} & \multirow[b]{2}{*}{$d^{* *}$} & \multirow[b]{2}{*}{ Observed potency } \\
\hline & $M$ & $S D$ & $M$ & $S D$ & & & & & \\
\hline PS1 & 2.50 & 1.591 & 3.24 & 1.865 & -3.698 & 175.79 & .000 & .44 & .977 \\
\hline PS2 & 3.06 & 1.585 & 3.87 & 1.641 & -4.566 & 194.46 & .000 & .50 & .995 \\
\hline PS3 & 2.20 & 1.432 & 2.91 & 1.654 & -3.958 & 177.67 & .000 & .47 & .988 \\
\hline PS4 & 3.14 & 1.498 & 4.13 & 1.748 & -5.586 & 176.29 & .000 & .63 & 1 \\
\hline PS5 & 2.25 & 1.680 & 3.26 & 2.039 & -4.651 & 171.19 & .000 & .56 & .999 \\
\hline PS6 & 1.85 & 1.403 & 2.33 & 1.614 & -2.798 & 178.28 & .006 & .32 & .843 \\
\hline PS7 & 1.96 & 1.453 & 2.65 & 1.787 & -3.595 & 169.58 & .000 & .44 & .975 \\
\hline PS8 & 1.95 & 1.313 & 2.41 & 1.615 & -2.697 & 166.53 & .008 & .32 & .838 \\
\hline PS9 & 2.18 & 1.460 & 3.29 & 1.836 & -5.721 & 166.92 & .000 & .70 & 1 \\
\hline PS10 & 3.23 & 1.687 & 4.14 & 1.721 & -4.827 & 197.07 & .000 & .52 & .998 \\
\hline PS11 & 2.84 & 1.710 & 4.27 & 1.911 & -7.235 & 182.41 & .000 & .81 & 1 \\
\hline PS12 & 1.82 & 1.288 & 3.15 & 1.960 & -6.609 & 148.51 & .000 & .88 & 1 \\
\hline
\end{tabular}

Note. PS1 = Difficulty falling asleep; PS2 = Migraines and headaches; PS3 = Gastrointestinal complaints; PS4. = Fatigue; PS5 =Tendency to eat, drink, or smoke more than usual; PS6 = Reduced sexual interest; PS7 = Dyspnea; PS8 = Loss of appetite; PS9 = Trembling; PS10 = Sharp pains in various parts of the body; PS11 = Strong temptation to stay in bed in the morning; PS12 =Tendency to sweat or palpitations.

*We used Student's $t$ test assuming inequality of variances because Levene's test was statistically significant at $p=.05$.

**Effect size: differences of standardized means.

Table 3

Contingency Table of Frequencies, Percentages (in brackets) and Residuals as a Function of Nonvictim / Victim and Stress Symptomatology(No Stress / Cases of Stress)

\begin{tabular}{llcc}
\hline & & \multicolumn{2}{c}{ Stress Symptomatology } \\
\cline { 3 - 4 } Nonvictims & & No stress & Cases of stress \\
\hline \multirow{2}{*}{ Victims } & Frequency (percentage) & $221(77.5)$ & $64(22.5)$ \\
& Standardized Residuals & 2 & -3.2 \\
\hline
\end{tabular}

Table 4

T Test for Independent Samples. Comparison of Employees who took Leave of Absence and Employees who did not, as a Function of Mobbing(NAQ-RE Score)

Leave of absence No leave of absence

$$
(n=102) \quad(n=286)
$$

\begin{tabular}{lccccccccc}
\hline & $M$ & $S D$ & $M$ & $S D$ & $T$ & $d f^{*}$ & $p$ & $d^{* *}$ & Observed potency \\
\hline Sum of NAQ-RE & 37.99 & 15.541 & 34.05 & 11.311 & 2.349 & 140.98 & .020 & .318 & .775 \\
\hline
\end{tabular}

Note. NAQ-RE = Negative Acts Questionnaire, Spanish revised version.

*We used Student's $t$ test assuming inequality of variances because Levene's test was statistically significant at $p=.05$.

**Effect size: differences of standardized means. 
Table 5

Pearson Correlations between Psychosomatic Symptoms (PCQ Score) and Mobbing Factors

\begin{tabular}{cccccr}
\hline & \multicolumn{5}{c}{ Mobbing Factors } \\
\cline { 2 - 6 } PCQ & NAQ1 & NAQ2 & NAQ3 & NAQ4 & NAQ5 \\
\cline { 2 - 6 } & .451 & .439 & .264 & .271 & .399 \\
\hline
\end{tabular}

Note: NAQ1 = Personal Bullying; NAQ2 = Work-related Bullying; NAQ3 = Age/Gender-related Bullying; NAQ4 = Organizational Bullying; NAQ5 = Other forms of Bullying. PCQ = Psychosomatic Complaints Questionnaire.

All correlations were significant at $p<.01$ (bilateral).

Table 6

Regression Analysis Summary for Predicting Psychosomatic Symptoms (PCQ Score)

\begin{tabular}{lcccc}
\hline Predictor variable & $\beta$ & $R$ & $R^{2}$ & $t$ \\
\hline Personal bullying (NAQ1) & .230 & .451 & .203 & 4.042 \\
Work-related bullying (NAQ2) & .218 & .498 & .248 & 3.933 \\
Other forms of bullying (NAQ5) & .178 & .520 & .270 & 3.426 \\
\hline
\end{tabular}

a low relation $(d=.318)$. In fact, if we made a contingency table of the categories of victims / nonvictims of mobbing and work absenteeism (yes / no), applying the chi square test, we would find no statistically significant differences between the groups, $\chi^{2}(1, N=2)=2.65, p=.123$, Cramer's $V=.083$.

Likewise, we used Student's $t$ test to verify whether the relation between the type of leave of absence and mobbing is significant. The reasons for leaves of absence were subdivided into two categories: those of a physical nature (work accidents, general physical complaints, flu, etc.) and those of a psychological nature (depression, anxiety attack, headaches, etc.). The results revealed no statistically significant differences, $t(1)=.0639, \alpha=.525$.

The second goal of this work was to analyze whether mobbing factors can predict stress-related psychosomatic symptomatology. For this purpose, we performed correlation analysis (see Table 5), using the total PCQ score and each of the five NAQ-RE components. The results yielded positive and significant associations.

Lastly, we carried out step-wise regression analysis, using the sum of the PCQ scores as the dependent variable and the various forms of mobbing as independent variables. The purpose of this analysis was to determine which forms of mobbing are the most adequate to predict psychosomatic symptoms. In Table 6 is presented the model resulting from step-wise regression analysis. As can be seen, the mobbing factors accounted for $27 \%$ of the global variance of the psychosomatic symptoms $\left(R^{2}=.27\right)$. Of the diverse kinds of bullying, work-related bullying, personal bullying, and other forms of bullying, in that order, had the highest predictive capacity.
Discussion

Current research on mobbing has underlined the need to incorporate its study and assessment into work risk prevention (Vartia, 1996; Einarsen, 1999, 2000; Hoel, Rayner, \& Cooper, 1999; Dupré \& Barling, 2003), as well as the need to estimate its incidence in diverse productive sectors and the consequences of this phenomenon in large samples, both at individual and organizational levels (Di Martino et al., 2003; Einarsen, 2000; Einarsen, Raknes, \& Matthiesen, 1994; Leymann, 1990). All of this was the starting point of the present study.

Any assessment of mobbing should begin by estimating the risk of mobbing, the number of workers who are exposed to mobbing, its consequences on individual health, and its effects on the organization. In the sector analyzed herein, we found a much higher rate of the incidence of bullying behaviors than estimations carried out in our country, which place it between 5 and 16\% (Paoli \& Merllié, 2001; Piñuel, 2001). Specifically, $28 \%$ of the workers suffer two or more bullying behaviors with a weekly or daily frequency. This shows that in this sector-where there the workers' protection systems (by the Régimen Especial Agrario [Special Agrarian Regime] (see CES, 2001) and the collectives employed (women and immigrants) are objectively discriminated, workers' professional preparation (training levels) is scarce, and certain aspects of the predominant company culture (highly hierarchized, male values) are prevalent - the workers are in a weak position, which makes them vulnerable to abusive and hostile behaviors. The explanation of the high percentage of incidence may be the conjunction of these diverse 
antecedents and because of the fact that we assessed the presence of different bullying behaviors, and not whether people felt themselves to be victims of workplace mobbing.

Regarding consequences on workers' health, in some studies carried out with global samples, higher levels of stress symptoms were found in victims than in nonvictims (Kaukianen et al., 2001; Mikkelsen \& Einarsen, 2002; Vartia, 2001; Zapf et al., 1996). Our work shows a significant relation between bullying and the specific stress symptoms presented in the PCQ, which leads us to assume a significant relation between mobbing and psychosomatic symptomatology. Therefore, organizations should be warned about the risk for workers' health represented by the presence of this phenomenon.

With regard to the percentage of variance of the psychosomatic effects accounted for by mobbing, it was the highest one found in the investigation: $26.5 \%$. Vartia (2001), also by means of regression analysis, concluded that being a victim of mobbing was a significant predictor of the stress symptoms included in her study, although she only explained $5 \%$ of the total variance. Einarsen et al. (1996) found that bullying accounted for $13 \%$ of the variance of psychological complaints, $6 \%$ of the muscular-skeletal problems, and $8 \%$ of the psychosomatic problems. In our case, we can also assume a significant association between bullying and psychosomatic symptomatology, and an increase in the cases of stress. Regarding absenteeism, although some studies show a relationship between bullying and work absenteeism (Kivimäki, Elovainio, \& Vahtera, 2000; Matthiesen, Racknes, \& Rökkum, 1989; Quine, 2001; Toohey, 1991; Vartia, 2001), with a negative effect both for workers and for the organization, our results are inconclusive. Several studies have found a rather weak relation between mobbing and work absenteeism (Einarsen \& Raknes, 1991; Hoel \& Cooper, 2000; UNISON, 1997), which supports the hypothesis that the relation between work absenteeism, mobbing, and the motive for taking leave may be conditioned by the pressure exerted by the company, either to come to work even if the worker is sick or to conceal the reason for the illness for fear of reprisals or prejudice within the organization (Hoel, Einarsen, \& Cooper, 2003). The pressure to come to work increases when individuals are aware that their nonattendance will have to be filled in by other coworkers, when there is a high risk of losing one's job, or when the victims do not want to be accused of malingering (Hoel et al., 2003). Such pressure can be so intense that sometimes it even becomes a form of mobbing (UNISON, 1997).

The above is also supported by the kind of behaviors or different forms of bullying; we know that negative behaviors that represent personal discredit (Einarsen \& Raknes, 1997; Mikkelsen \& Einarsen, 2002; Zapf et al., 1996), such as assigning meaningless tasks, not responding to suggestions and opinions, or being ignored (Vartia, 2001), have a higher relation with psychological health problems. In our study, the bullying behaviors that best predicted psychosomatic complaints were personal bullying and work-related bullying, together with other forms of bullying, which reinforces this hypothesis.

Summing up, our present findings show that the problem of mobbing can and should be considered within the framework of prevention of workplace risks, as a phenomenon that affects workers' health, whether or not the workers have labeled themselves as mobbing victims. And by applying preventive policies to this phenomenon, especially to work-related bullying behaviors and personal attacks, the emergence of psychosomatic symptomatology will be reduced.

Regarding the limitations of this work, we would like to point out the correlational nature of the conclusions about the relations between mobbing and workers' health. Mobbing can be considered both a cause and a consequence of the presence of psychosocial risk factors. However, according to our results, the antecedents of mobbing are mainly found in the organizational context and not so much in the individual variables of bullies and victims (Hoel et al., 1999).

The data were collected by means of self-report. In such a complex phenomenon as mobbing, it would be more appropriate to count on other sources of information in order to contrast the data. Thus, the use of personal interviews with workers who feel they are mobbing victims and the opinion of people who were identified as bullies could be relevant sources of information for the study of this phenomenon, although this would doubtless be difficult to carry out.

A third limitation is the lack of adaptation of the measuring instruments to the immigrant population. This topic is increasingly relevant as these collectives of workers increase. In our investigation, this was compensated by the presence of a technician in workplace risk prevention during the process of administration of the questionnaires. In the future, research should continue with studies of nonvictims and verify the usefulness of the NAQ-RE as an indicator of psychosocial problems in companies. For this purpose, the adaptation of this measuring instrument to specific populations and sectors is urgently required.

\section{References}

Brodsky, C.M. (1976). The harassed worker. Toronto: Lexington Books.

Cohen, J. (1988). Statistical power analysis for the behavioral sciences ( $2^{\text {nd }}$ ed.). Hillsdale, NJ: Erbaum.

Consejo Económico y Social de la Región de Murcia (2003). Condiciones de trabajo en el sector agroalimentario de la Región de Murcia. Murcia, Spain: CES

Di Martino, V., Hoel, H., \& Cooper, C.L. (2003). Preventing violence and harassment in the workplace. Dublin: European Foundation for the Improvement of Living and Working Conditions. 
Dupré, K.E., \& Barling, J. (2003). Workplace aggression. In A. Sagie, M. Koslowsky, \& S. Stashervsky (Eds.), Misbehaviour and dysfunctional attitudes in organisations. New York: Palgrave Macmillan

Einarsen, S. (1999). The nature and causes of bullying at work, International Journal of Manpower, 20, 16-27.

Einarsen, S. (2000). Harassment and bullying at work: A review of the Scandinavian approach. Aggression and violent behavior, $5,379-401$.

Einarsen, S., \& Hoel, H. (2001, May). The Negative Acts Questionnaire: Development, validation and revision of a measure of bullying at work. $10^{\text {th }}$ European Congress on Work and Organisational Psychology. Prague.

Einarsen, S., Matthisen, S., \& Skogstad, A. (1998). Bullying, burnout and well-being among assistant nurses. Journal of Occupational Health \& Safety, 14, 563-568.

Einarsen, S., \& Raknes, B.I. (1991). Mobbing i Arbeidslivet. En Undersolkelse av forchomst og helsemessige konseckvenser av mobbing $i$ pä norske arbeidsplasser. FAHS, Bergen: Universitetet i Bergen.

Einarsen, S., \& Raknes, B.I. (1997). Harassment at work and victimization of men. Violence and Victims, 12, 247-263.

Einarsen, S., Raknes, B.I., \& Matthiesen, S.M. (1994). Bullying and harassment at work and their relations to work environment quality. An exploratory study. The European Work and Organizational Psychology, 4, 381-401.

Einarsen, S., Raknes, B.I., Matthiesen S.B., \& Hellesoy O.H. (1996). Helsemessige aspekter ved mobbing i arbeidslivet. Modererende effekter av sosial sttotte og personlighet. Nordisk Psykologi, 48, 116-137.

Gandolfo, R. (1995). MMPI-2 profiles of worker's compensation claimants who present with claimant of harassment. Journal of Clinical Psychology, 51, 711-715.

García-Izquierdo, M., Castellón, M., Albadalejo, B., \& GarcíaIzquierdo, A. (1993). Relaciones entre el burnout, ambigüedad de rol y satisfacción laboral en el personal de la Banca. Revista de Psicología el Trabajo y de las Organizaciones, 11, 17-26.

Hock, R.R. (1988). Professional burnout among public school teachers. Public Personnel Management, 17, 167-189.

Hoel, H., Einarsen, S., \& Cooper, C.L. (2003). Organisational effects of bullying. In S. Einarsen, H. Hoel, D. Zapf, \& C.L Cooper (Eds.), Bullying and emotional abuse in the workplace: International perspectives in research and practice. London: Taylor \& Francis.

Hoel, H., \& Cooper, C.L. (2000). Destructive conflict and bullying at work. Unpublished report: University of Manchester, Institute of Science and Technology. Available upon request from the author at Helge.Hoel@umist.ac.uk.

Hoel, H., Rayner, CH., \& Cooper C.L. (1999). Workplace bullying. In C.L. Cooper \& I.T. Robertson (Eds.), International Review of Industrial and Organizational Psychology (pp. 195-230). Chichester, UK: John Wiley \& Sons.

Kaukiainen, A., Salmivalli, C., Björkqvist, K., Österman, K., Lahtinen, A., Kostamo, A., \& Lagerspetz, K. (2001). Overt and covert aggression in work setting in relation to the subjective well-being of employees. Aggressive Behavior, 27, 360-371.
Keashly, L., \& Harvey, S. (2006). Emotional abuse at work. In E.K. Kelloway, J. Barling,, \& J. Hurrell (Eds.), Handbook of workplace violence (pp. 95-120). California: Sage.

Kivimäki, M., Elovainio, M., \& Vahtera, J. (2000). Workplace bullying and sickness absence in hospital staff. Occupational and Environmental Medicine, 57, 656-660.

Leymann, H. (1990). Mobbing and psychological terror at workplaces. Violence and Victims, 5, 119-126.

Leymann. H. (1996). The content and development of bullying at work. European Journal of Work and Organisational Psychology, 5, 165-184.

Leymann, H., \& Gustafsson, A. (1996). Mobbing and the development of PTSD. European Journal of Work and Organisational Psychology, 5, 251-275.

Llor, B., García-Izquierdo, M., Campillo, M.J., Ruiz, J.A., \& Luna, A. (2004, April). Características de personalidad y mobbing. Oral communication presented at the XII National Congress of Legal Psychiatry. Málaga, Spain.

Matthiesen, S.B., \& Einarsen, S. (2001). MMPI-2 configurations among victims of bullying at work. European Journal of Work and Organizational Psychology. 10, 467-484.

Matthiesen, S.B., Raknes, B.I., \& Rökkum, O. (1989). Mobbing pa arbeidsplassen. Tidsskriftfor Norsk Psykologforening, 26, 761-774.

Meseguer, M. (2005). El acoso psicológico en el trabajo (mobbing) y su relación con los factores de riesgo psicosocial en una empresa hortofrutícola. Unpublished doctoral thesis. Universidad de Murcia. Available upon request from the author at marianom@um.es.

Mikkelsen, E.G., \& Einarsen, S. (2001). Bullying in Danish worklife: Prevalence and health correlates. European Journal of Work and Organizational Psychology, 10, 393-413.

Mikkelsen, E.G., \& Einarsen, S. (2002). Relationships between exposure to bullying at work and psychological and psychosomatic health complaints: The role of state negative affectivity and generalized self-efficacy. Scandinavian Journal of Psychology, 43, 397-405.

Ministerio de Trabajo y Asuntos Sociales. MTAS (2004). V Encuesta Nacional de Condiciones de Trabajo. Madrid: A. Almodóvar (Coord.).

Paoli, P., \& Merllié, D. (2001). Third European survey on working conditions in the European Union (2000). European Foundation for the Improvement of Living and Working Conditions. Luxemburg: Office for the Official Publications of the European Communities.

Piñuel, I. (2001). Estudio Barómetro Cisneros II. Madrid: Universidad de Alcalá de Henares.

Quine, L. (2001). Workplace bullying in nurses. Journal of Health Psychology, 6, 73-84.

Sáez, M.C., García-Izquierdo, M., \& LLor, B. (2003). Validación de la escala NAQ de Einarsen y Raknes (1997) sobre acoso psicológico en el trabajo (mobbing). Communication presented at the VIII National Congress of Social Psychology, in the Symposium of Mobbing: una perspectiva psicosocial. Torremolinos, Málaga (Spain). 
Toohey, J. (1991). Occupational stress: Managing a metaphor. Sydney: Macquarie University.

UNISON (1997). UNISON members' experience of bullying at work. London: UNISON.

Vartia, M. (1996). The sources of bullying: Psychological work environment and organizational climate. European Journal of Work and Organizational Psychology, 5, 203-214.

Vartia, M. (2001). Consequences of workplace bullying with respect to the well-being of its targets and the observers of bullying. Scand Work Environ Health, 21, 63-69.

Vartia, M. (2003). Workplace bullying; A study on the work environment, well-being and health. People and Work Research Reports 56. Finnish Institute of Occupational Health.
Wilson, B.C. (1991). U.S. Businesses suffer form workplace trauma. Personnel Journal, July, 47-50.

Zapf, D. (1999). Organisational, work group related and personal causes of mobbing / bullying at work. International Journal of Manpower, 20, 70-85.

Zapf, D., Knorz, C., \& Kulla, M. (1996). On the relationship between mobbing factors, and job content, social work environment, and health outcomes. European Journal of Work and Organizational Psychology, 5, 215-237.

Received March, 29, 2006

Revision received April, 30, 2007

Accepted June, 26, 2007 